\title{
酸化窒素ガスのナイロン䋐維への収着と反応

\begin{tabular}{|c|c|c|}
\hline 京都工芸䄉維大学工芸学部 & 上田 & 充夫 - 小林 弘明 ${ }^{* 1}$ \\
\hline & 岩田 & 彬·脇田登美司 \\
\hline 大阪市立工業研究所 & 伊丹 & 正郎 \\
\hline
\end{tabular}

\section{Sorption and Reaction of Nitrogen Oxide on Nylon 6}

\author{
Mitsuo Ueda ${ }^{* 1}$, Hiroaki Kobayashi ${ }^{* 1.2}$, Akira Iwata*2, Tomiji Wakida ${ }^{* 2}$, and Masao Itami ${ }^{* 3}$ \\ *2 Department of Chemistry and Materials Technology, Faculty of Engineering and Design, Kyoto Institute of \\ Technology, Matsugasaki, Sakyo-ku, Kyoto, 606 Japan \\ *3 Department of Mechanical Engineering, Osaka Municipal Technical Research Institute, Morinomiya, \\ Joto-ku, Osaka, 536 Japan
}

\begin{abstract}
Sorption and reaction of nitrogen dioxide on nylon substrate were investigated for the study of yellowing of fabrics on storage under the atmosphere. Yellowed nylon fabrics after exposure to $\mathrm{NO}_{2}$ gas were found to have two distinguishable visible absorption maxima at 390 and $440 \mathrm{~nm}$. These two absorptions changed in magnitude independently with the period of exposure to $\mathrm{NO}_{2}$ gas. XPS spectra of the yellowed nylon suggested that NO groups were introduced on the substrate by the exposure to $\mathrm{NO}_{2}$ gas. FTIR spectra also indicated that nitrosoamine was formed on nylon substrate. Sorption of $\mathrm{NO}_{2}$ on dry and wet nylon samples was measured by the Saltzman method. The sorption of $\mathrm{NO}_{2}$ on wet nylon and resulting yellowing of the substrate were more remark. able than those for dry nylon.
\end{abstract}

(Received April 6, 1994)

\section{1. 粕 言}

近年、峨維が環境中に保管する間に黄変を起こす事故 がしばしば発生し，品質管理上の大さな闍題となってい る。このような轼維の保管中の黄变は，主として環境中 の燃焼ガスによってもたらされるものであると考えられ ている。䄉維基質そのもの，あるいは蝁光染料，織維加 工剂，酸化防止剤など，戥維基質中の種々の共存物侗が 保管中に大気中の燃焼ガスと反応し，種々の黄色の物質 が生成するものと推定されている[1，2]。燃焼ガスのう

*1 現在の所属: 株式会社川島織物, 中央技術 - 文化セ 之夕-

Present address: Main Center of Culture \& Technolo-

gy, Kawashima Textile Manufactures Ltd., 265 Ichihara-cho, Shizuichi, Sakyo-ku, Kyoto, 601-11 Japan
ちで最も影鄂が大きいものとして酸化等素がス（NOX） があげられるが，硫黄酸化物 $\left(\mathrm{SO}_{\mathrm{X}}\right)$ や硫化水素 $\left(\mathrm{H}_{2} \mathrm{~S}\right)$

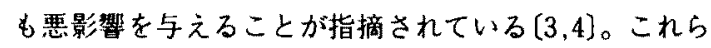
の然焼ガスの染色堅本性に対する影謺については古くか ら研究され[5-8]，ガスの基質中への収着性と反応活性 が影響を左右するものと推定されている。䢂維の黄変の 問題に関しても，燃焼ガスの基質への吸収及びその活性 が直接影響を与えるものと推定できるが，現在までに詳 細に検討された例がなく，まだ不明な点が多い。そこで， 本研究では，燃焼ガスと栈維基質との反応を可視部反射 スペクトル，X線光電子分光法 (XPS) およびフーリエ 変換赤外分光法（FTIR）によって娭討するとともに， 織維基質に吸収される燃焼ガスの量とその速度に関して 検討を加えた。

黄変には種々の因子が考えられるが，本研究は系を簡 単にするため，基質にナイロン 6 織維およびフィルムを 選び，燃焼ガスの代表例として，最も織維の黄変に影瑤 


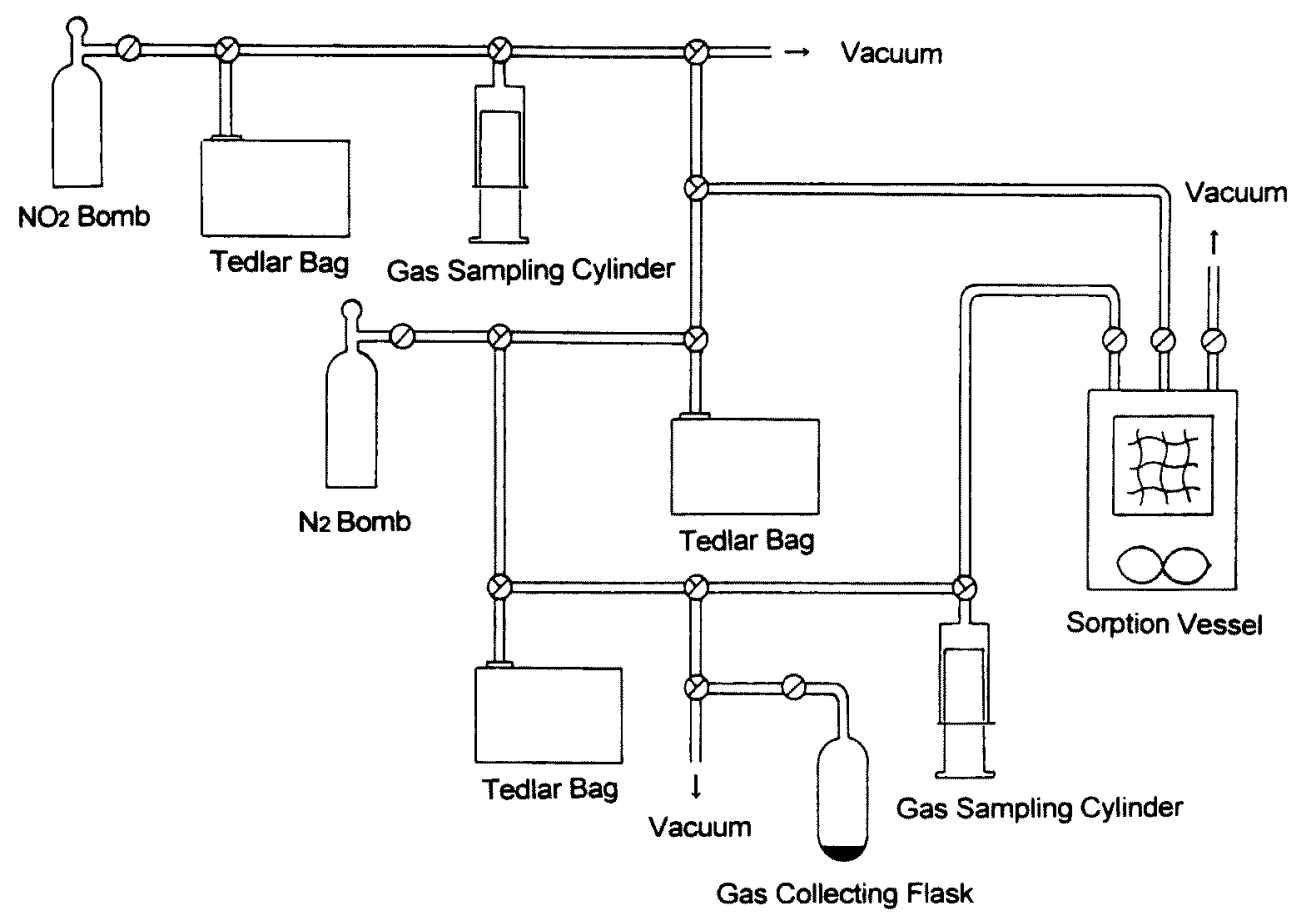

Fig. 1 Apparatus for measuring sorption of $\mathrm{NO}_{2}$ on fiber.

が大きいとされる二酸化窒素 $\left(\mathrm{NO}_{2}\right)$ ガスを選んだ。

\section{2. 実跧方法}

基質には染色堅牢度試験用添付白布（JIS L 0803） のナイロン 6 フィラメント織物および 2 軸延伸ナイロン 6 フィルム（厚さ15 $\mu \mathrm{m}$ ) をあらかじめ熱湯で 2 時閏 処理し，構造を安定化させたのち使用した。

二酸化窒素ガスは窒素によって $\mathrm{NO}_{2}$ 濃度を $10000 \mathrm{ppm}$ に希釈調整したボンべから供給し，適宣，窒素でさらに 所定の浱度に希釈して使用した。

挠維に対する二酸化窒素の収着および反応の実験はい ずれも密閉系で行った。実験に使用した装置の概略を図 1 に示す。収着反応槽は硬質ガラス製で $4 \mathrm{~L} の$ 容量のも のである。内部のガス渾度を均一にするために外部から マダネチックスターラーで筧找できるようになっている。 各ジョイントにはテフロンチューブおよびガラスコック を用いた。ガスの希釈及び導入はガラスシリンジとテド ラーバッグを用いておこない，あらかじめ試料をセット した収着反応槽を真空にしておき，必要量の二酸化窒素 ガスと窒素ガスをそれぞれのボンベからテドラーバック を通してシリンジで採取し収着反応槽に導入した。

找維に収着した二酸化窒素ガス成分の定量は，サンプ ルを収着反応槽から取り出し，収着した二酸化窒素を試 薬により発色させたのち分光学的に測定した。また，収
着反応の後，気相中に残存する二酸化窒素ガスは収着反 応槽から再びシリンジでガスを一定量採取の後，蒸留水 に溶解抽出の後, 発色, 定量した。二酸化窒素の発色に はいずれもスルファニル酸とN-(1-ナフチル)エチレン ジアミンとのアゾカップリング反応を応用したいわゆる ザルッマン法 [9]を用いた。これらの収着及び反応実験 はすべて20士2 ${ }^{\circ} \mathrm{C}$ の環境下で行った。

発色による二酸化窒素の定量には日立製作所製紫外可 視分光光度計340型を，また試料布の分光反射率の測定 には日立製作所製カラーアナライザー307型を用いた。 赤外吸収スペクトルの測定にはパーキンエルマー社製の FTIR 分光光度計 1650 型を用いKRS 5 による多重反射法 によって行なった。またX線光電子分光スペクトルは島 津製作所製の ESCA-750を用いて測定した。

\section{3. 結果と考察}

収着反応槽内の二酸化窒素濃度を $10000 \mathrm{ppm}$ に設定 し，ナイロン 6 戟維を密閉系において 2 時間および 24 時 間暴露した際の䄉維試料の分光反射スペタトルを示した のが図 2 である。2 時間の暴露で $390 \mathrm{~nm}$ と440 $\mathrm{nm}$ 付近 に吸収が現れ，黄変を起こしていることがわかる。さら に暴露を続けると，24時間後には390 nm の吸収が增加 し，逆に440 nm 付近の吸収が減少する。390 $\mathrm{nm}$ およ び440 $\mathrm{nm}$ の吸収が暴露時間によってどのように变化す 


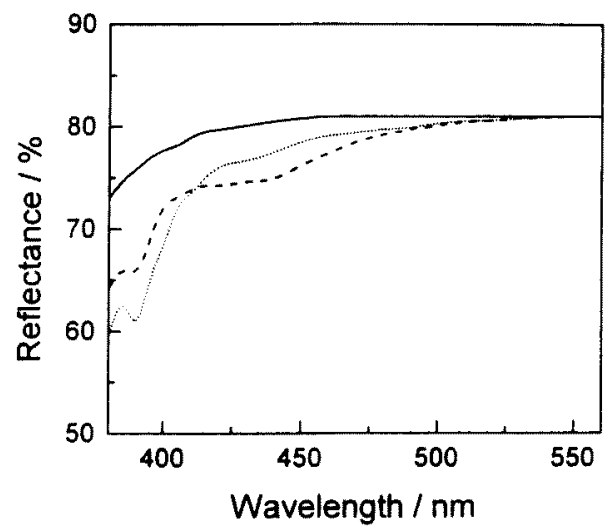

Fig. 2 Reflection spectra of nylon fabrics: - original; - - exposed to $10000 \mathrm{ppm} \mathrm{NO}_{2} / \mathrm{N}_{2}$ gas for $2 \mathrm{~h}$; $\cdots$, exposed to $10000 \mathrm{ppm} \mathrm{NO}_{2} / \mathrm{N}_{2}$ gas for $24 \mathrm{~h}$.

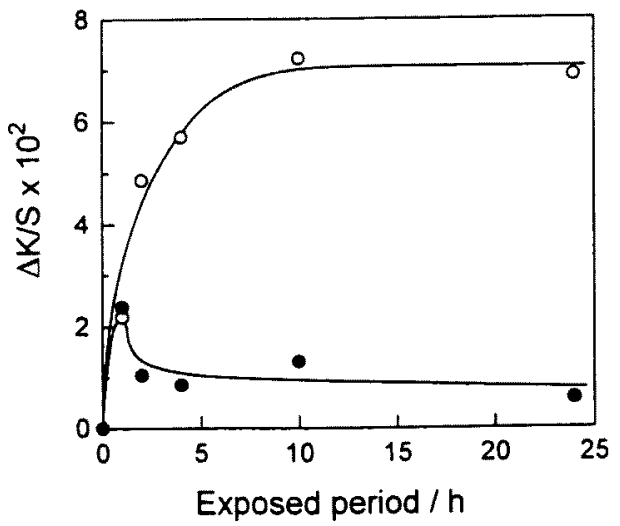

Fig. 3 Change in $K / S$ value of nylon as a function of exposure period: Initial concentration of $\mathrm{NO}_{2}, 10000$ ppm; $\bigcirc$, at $390 \mathrm{~nm}$; at $440 \mathrm{~nm}$.

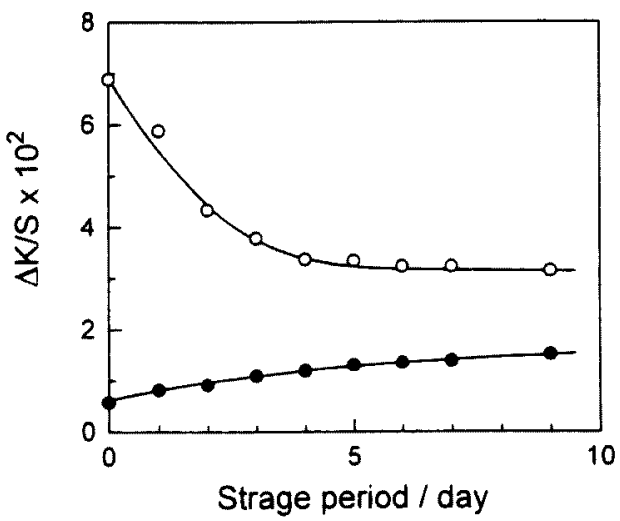

Fig. 4 Change in $\mathrm{K} / \mathrm{S}$ value of nylon as a function of storage period in pure $\mathrm{N}_{2}$ gas: $\mathrm{O}$, at $390 \mathrm{~nm}$; at 440 $\mathrm{nm}$.
るかを示したのが図 3 である。390 nm 及び440 nmに おける反射スペクトルの $\mathrm{K} / \mathrm{S}$ 值 $\left(\mathrm{K} / \mathrm{S}=(1-\mathrm{R})^{2}\right.$ /2R， R は反射率) をとり，暴露前の試料との $\mathrm{K} / \mathrm{S}$ 値の差すなわち $\Delta \mathrm{K} / \mathrm{S}$ を暴露時間に対してプロットし たものである。図 2 および図 3 からわかるように,十イ ロン䄉維の二酸化坴素による黄変は複雑な様相を示して おり，390 nmの吸収は，暴露時間の増加に伴ってさら に増大するが, $440 \mathrm{~nm}$ の吸収は暴露初期に現れ，その 後，低下する傾向を示している。このことは，二酸化䇪 素の暴露によるナイロンの黄変は，単一の黄色成分の生 成によるものではなく，少なくとも二種類以上の黄色成 分が関与して扔り，且つその成分が時間とともに增减す ることを示している。図 4 は24時間暴露し黄変した轹維 を100\%窒素ガス中に保存したときの390 nm と440 nm の黄色成分の变化を示したものである。黄变後の轿維を 二酸化空素のない㦚素ガス中に保存すると，390 nmの 成分が滅少し，440 nm の成分が増加する傾向にある。 気体状態の二酸化空素が400 nmに吸収を持っているこ と〔10)から, 基質上の390および440 $\mathrm{nm}$ の吸収のうち のいずれかが収着した二酸化窒素分子そのものの吸収で， 他方が基質との反応生成物の吸収であるうと推定できる。 可視スペクトルのみからいずれが二酸化空素の吸収であ るかは不明であるが，図4のように，暴露後，筀素中に 保管することによって390 nm の吸収が急激に指数関数 的に滅衰することから，この吸収が二酸化穻素の収着に 基づくものである可能性が高い。

つぎに，暴露後に基質にどのような化学的な変化が起 こっているかについて調べるために，10000 ppmの二 酸化等素で24時間暴露したナイロン 6 フィルムのXPS スペクトルを測定し图 5 に示した。暴露前と暴露後の十 イロン6フィルムの $\mathrm{C}_{1 \mathrm{~s}}, \mathrm{O}_{1 \mathrm{~S}}$ および $\mathrm{N}_{1 \mathrm{~S}}$ のスペクトルを 示したものである。表 1 にはそれぞれの元素の見掛けの 相対スベクトル面積比と各元秦の存在比率を示した。各 元素のスペクトル形状には影著な変化は見られないが, わずかに炭素と峌素のスペクトルの高エネルギー側に若 干のピークあるいはショルダーの出現が見られる。この

Table 1 Peak Areas of XPS Spectra of Nylon Fabrics Apparent peak area(\%) Relative peak area

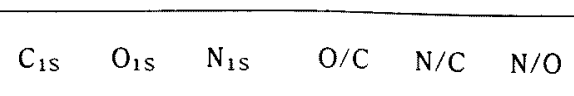

$\begin{array}{lllllll}\text { Original } & 84.2 & 12.3 & 3.5 & 0.145 & 0.041 & 0.284 \\ \text { Exposed } & 80.2 & 15.4 & 4.4 & 0.192 & 0.054 & 0.281\end{array}$



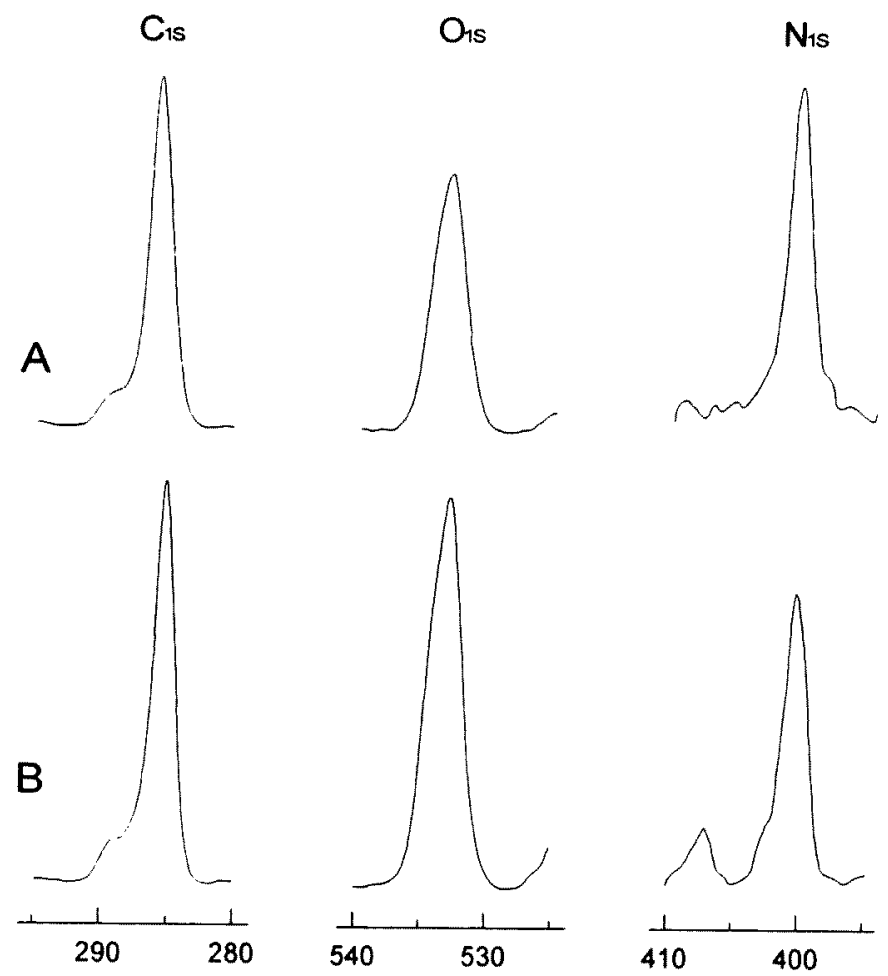

Binding energy/eV

Fig. 5 XPS spectra of nylon fabrics: A, Original; $\mathrm{B}$, exposed to $10000 \mathrm{ppm} \mathrm{NO}_{2}, \mathrm{~N}_{2}$ gas for $24 \mathrm{~h}$.

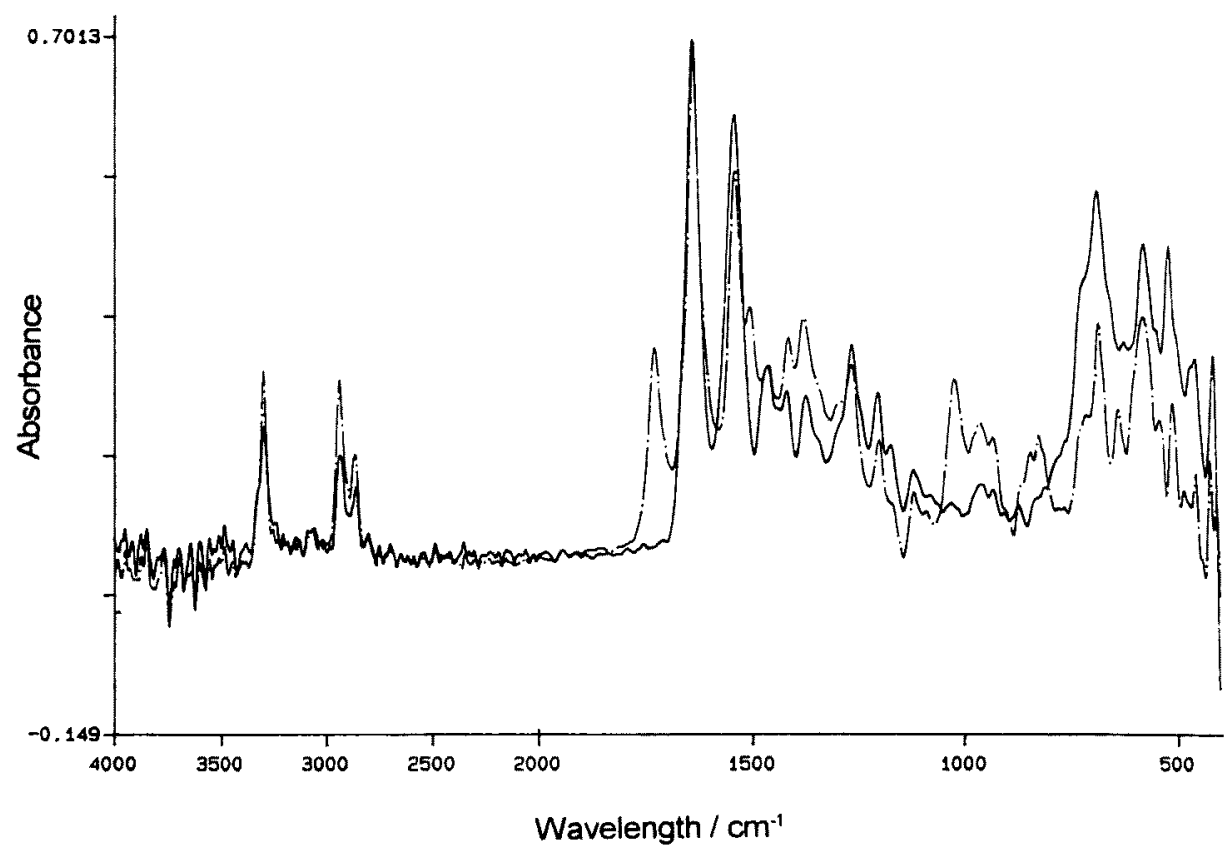

Fig. 6 FTIR spectra of nylon fabrics: -, original; - - - exposed to $10000 \mathrm{ppm} \mathrm{NO}_{2} / \mathrm{N}_{2}$ gas for $24 \mathrm{~h}$. 
ことは、二酸化窒素ガスの暴露によって基質の炭素拉よ び窒素原子がより電子吸引性の結合を伴うようになった ことを示唆するもので，暴露によって基質の酸化，ニト ロソ化、ニトロ化, 亜硝酸エステル化あるいは酸化窒素 の収着などが起こっているものと推定できる。表1の見 掛けのピーク面積比の変化を見ても，暴露後の窒素と酸 素の增加を示しており，また，酸素／炭素比，窒素／炭 素比の变化は，暴露による基質への酸素と窒素の導入を 示啳している。穻素/酸素の比が暴露によ゙って大きく变 化していないことから，NOのかたちで窒素と酸素が導 入されると考えることも可能である。

同様の二酸化窒素暴露ナイロン 6 フィルムの FTIR ス

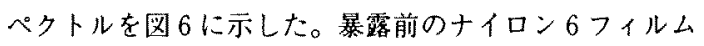
と暴露後のフィルムとの大きな変化は，1700，1400およ び1000 $\mathrm{cm}^{-1}$ 付近にポリアミド以外の新たな吸収が現れ ていることである。赤外吸収スペクトルだけから官能基 を断定するのは困難であるが，1400および1000 $\mathrm{cm}^{-1}$ 付 近の吸収の増加はニトロソアミンの生成を示唆している。 また1700 $\mathrm{cm}^{-1}$ の吸収はカルボキシル，アルデヒドある いはケトンの生成が考えられる。十イロン基質のアミ， 基が二酸化窒素によってニトロソ化され，同時に一部が 脱窒素し，非アミド采のカルボニル基が生成しているの ではないかと考えられる。このような推定は图 5 の XPSのスペクトルが $\mathrm{C}_{1 \mathrm{~S}}$ および $\mathrm{N}_{1 \mathrm{~S}}$ の双方について高工 ネルギー側にピークあるいはショルダーが生成している 事実によっても支持される。

以上のように，可梘吸収スペクトル，XPSおよび FTIRによる検討結果を総合して，二酸化窒素がスによ るナイロン 6 の黄変の原因は基質上への二酸化窒素の収 着とニトロソアミンの生成であることが推定できる。し かしながらこのようなわずかなスベクトルデータのみ から断定することは不可能で，今偻，さらに詳細な検討 を進める必要がある。

つぎに，二酸化窒素ガスのナイロン6 溨維に対する収 着の測定結果について述べる。困 7 は暴露当初の二酸化 空素濃度を $10 ， 100 ， 1000 ， 10000 \mathrm{ppm}$ とし，1時間密 閉系で暴露したときの1gのナイロン䄉維に収着する二 酸化窒素のモル数を定量したものである。䄉維基質には 乾燥状態のナイロンと湿潤状態（100\%しぼり）の場合 との2種の状態で比較した。1時間の暴露によっても二 酸化空素はナイロンに収着するのみでなく基質と反応し て検出されなくなる部分があると推定できるが、ここで は，基質上に収着した活性の二酸化窒素のみを定量した。 四7からわかるように，二酸化空素のナイロンへの収着 はガス中の二酸化窒素量が100 ppmを越すあたりから 急激に増加し1000 ppm 程度でプラトーに達する。また

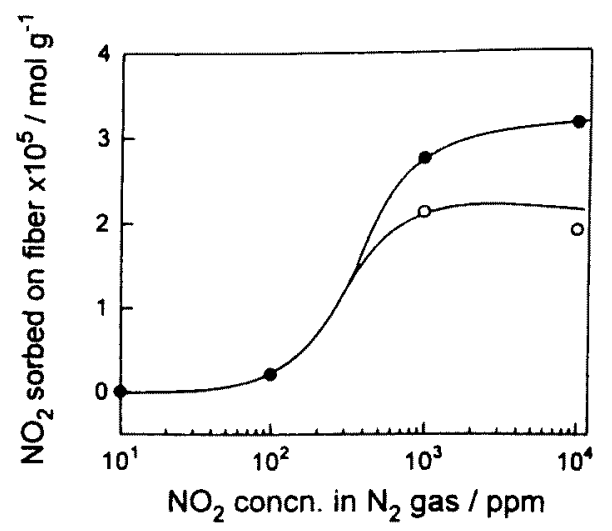

Fig. 7 Sorption of $\mathrm{NO}_{2}$ on nylon as a function of initial concentration of $\mathrm{NO}_{2}$ in $\mathrm{N}_{2}$ (exposed for $1 \mathrm{~h}$ ) : $\mathrm{O}$, dry nylon; wet nylon ( $100 \%$ pick-up).

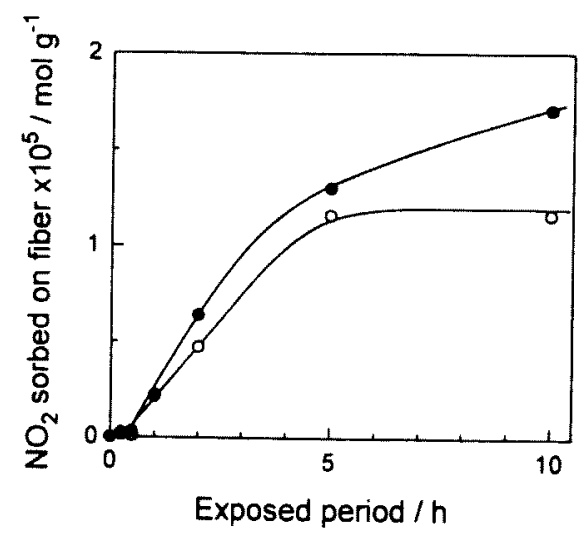

Fig. 8 Sorption rate of $\mathrm{NO}_{2}$ on nylon: Initial concentra. tion of $\mathrm{NO}_{2}, 100$ ppm; $\mathrm{O}$, dry nylon; $\mathrm{O}$, wet nylon (100\% pick-up).

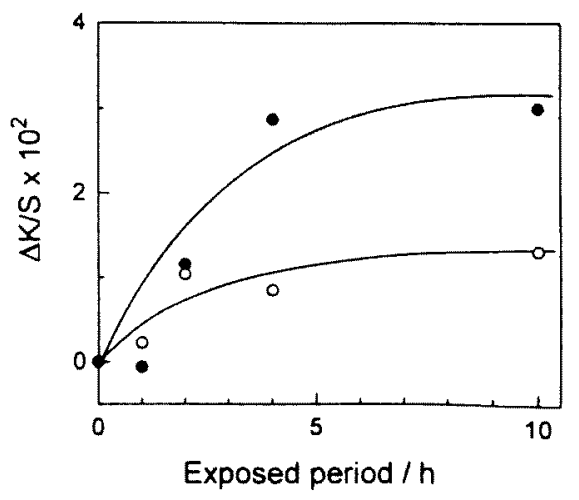

Fig. 9 Change in $\mathrm{K} / \mathrm{S}$ value of nylon at $440 \mathrm{~nm}$ as a function of exposure period: Initial concentration of $\mathrm{NO}_{2}$, $100 \mathrm{ppm}$. 
その際の収着量は湿潤䄉維の方が乾燥轵維よりも高い。 このことは，一般に環境中に $100 \mathrm{ppm}$ 程度の酸化室素 搌度がある場合に䄉維が保管中に黄変を起こす事故が顕 著であること，また，桟維が湿潤するような環境にある ほど黄变の事故が多いことなどの実際の経駼的事春と定 性的に一致するものである。また，酸化空素による染色 物のガス退色の場合，環境の湿度が离いはどガス退色が 著しいという事害[8]とも定性的に一致する。しかしな がら，本害験の場合，1000 ppm 以下の二酸化窒素濃度 環境下での 1 時間程度の暴露では実験試料の黄変はほと んど認められなかった。図2にも示しているように， $10000 \mathrm{ppm}$ の高濃度環境下で若干の黄変が認められた 程度であった。

実際の産業界では $100 \mathrm{ppm}$ 程度の低濃度の環境下で ナイロン峨維が顕著に黄変する問題が発生しているが, これは図 7 に示したように，基質にまず二酸化窒素が収 着した後に，長時間にわたる基質との反応によって初め て顕著な黄变が現われてくるものと推定できる。そこで， 初期濃度 $100 \mathrm{ppm}$ におけける二酸化窒素の十イロン縺 維への収着の速度を測定したのが図 8である。初期濃度 $100 \mathrm{ppm}$ の密閉系環境下でナイロン糃維を暴露し，暴 露時間にともなう轹維への二酸化呿素の収着量を定量し たものである。低濃度環境下での二酸化空素の䄉維への 収着速度は比較的荤く, 乾燥䋞維, 湿潤轹維とも同椂の 速度を示しているが，湿潤䄉維の場合は10時間後におい てもまだ収着量が増大する傾向にあるのに対し，乾燥䋐 維の場合は暴露 5 時間で飽和に達している。湿潤諓維が 水の影響で多量の二酸化空素を取着し蓄皘するこを示唆 している。図 9 は同样に初期濃度 $100 \mathrm{ppm}$ で暴露した 場合のナイロン織維の黄変の速度を440 nmにおける ノS 值の変化で表示したものであるが，黄変は比較的長 時間を要して発生し，また，湿阔械䧽の力が乾燥峨維よ りも黄変が顕著であることを示している。轹維が水で湿 閏しているとなぜ二酸化窒素の収着量が多く、また黄变 が顕著になるかについては現在のところ明確ではない。 ナイロン基質内部および表面に水が存在すると, 二酸化 咥素が基質に吸着するのみならず水を溶媒として溶解し て存在する可能性も考えられる。また，水がナイロンと
二酸化窒素との反応に関与している可能性も否定できな w。

\section{4. 結}

二酸化公素ガスのナイロン 6 に対寸る取着と反心につ いて検討し次の結論を得た。

1) 二酸化窒素ガスによるナイロン 6 䄉維の黄変は, 可 視部390 nmの吸収に起因するものと，440 nm の吸 収に起因するものとがあり，それらの可視部吸収が互 いに暴露時間および保管時間とともに变化する。

2）二酸化窒素による暴露でナイロン基質にはニトロソ 基と非アミド系のカルボニル基に基づくと考えられる 赤外吸取が検出され，かつXPS 分析結果からもNO の基筫への導入が示唆される。

3 ）二酸化空素の十イロン基質への収着は暴露初期濃度 が100 ppm 以上で顕著であり，1000 ppmの初期濃度 ではほほブラトーに達する。また収着量は瀻維が湿潤 状態の場合の方が多い。

4) 低濃度環境下に掞ける二酸化窒素の十イロン基質へ の収着と黄变の速度は比較的緩やかで, 収着量と黄变 の程度は，ともに湿閏状態の場合の方が著しい。

\section{文祆}

1. V. S. Salvin, National Tech. Conf., AA TCC,40 (1974).

2. V. G. Agnihotori, Colorage, 22, 25 (1975).

3. M. Makansi, Tex. Chem. Color., 18, 52 (1986).

4. J. A. Grant, Clothing Research J., 6. 11 (1978).

5. F. M. Rowe ang K. A. J. Chamberlain, J. Soc. Dyers Colour., 53, 268 (1937).

6. V. S. Salvin, W. D. Paist, and W. J. Myles, Am. Dyest. Reptr., 41, 297 (1952).

7. 芳住邦雄, 越川爵一, 「日本学術振興会染色堅万う 度第134委員会業績報告」, VoL.14, p.133 (1991).

8. K. Yoshizumi and J. Koshikawa, Sen'i Gakkaishi, 48, 663 (1993).

9. 「日本工業規格」, JIS K 0104-1984.

10. 「化学便覽」基礎編 II 改訂 4 版，p. II -606（1993）. 